\title{
Polysèmes
}

Revue d'études intertextuelles et intermédiales

\section{Black Magic in A.S. Byatt's Little Black Book of Stories: Painting the Body Sublime}

Magie noire et magie du noir : le corps sublime dans les Petits Contes noirs

d'A.S. Byatt

\section{Émilie Walezak}

\section{(2) OpenEdition}

\section{Journals}

Electronic version

URL: http://journals.openedition.org/polysemes/604

DOI: $10.4000 /$ polysemes. 604

ISSN: 2496-4212

Publisher

SAIT

Electronic reference

Émilie Walezak, "Black Magic in A.S. Byatt's Little Black Book of Stories: Painting the Body Sublime », Polysèmes [Online], 14 | 2015, Online since 18 November 2015, connection on 09 October 2020. URL http://journals.openedition.org/polysemes/604 ; DOI : https://doi.org/10.4000/polysemes.604

This text was automatically generated on 9 October 2020.

Polysèmes 


\title{
Black Magic in A.S. Byatt's Little Black Book of Stories: Painting the Body Sublime
}

\author{
Magie noire et magie du noir : le corps sublime dans les Petits Contes noirs
}

d'A.S. Byatt

Émilie Walezak

1 A.S. Byatt's interest in painting and colour is well-known and manifest in such eloquent titles as Still Life, The Matisse Stories, "Rose-Coloured Tea Cups", "Art Work", "Body Art". She has explained on numerous occasions how a book, whether a novel or a collection of short stories, first shapes itself in her mind through colours: "I like to write about painting because I think visually. I see my writing as blocks of color before it forms itself" (Burns). It all starts with colours, so much so that, for instance, the pivotal figure of Van Gogh in Still Life only became so because she felt the need to use a complementary yellow in a book she thought of as purple. ${ }^{1}$ Thus Byatt's "colour vision" (Byatt 1998, 71) is a key factor to uncover the leading patterns of her books. This is very much the case with Little Black Book of Stories. The very title of the collection sets the tone for its five short stories. The black colour also dominates the book's cover in its various editions, which contrasts greatly with the vivid colours of Byatt's previous collections. Aptly enough, the five stories are quite dark and could be labelled as domestic horror tales as they focus on the darkest aspects of British national history, namely World War 2, and of the body's personal story, whether the ageing body or the abused body. Coupling the body politic with intimate anatomy, the artistic with the ordinary, the black colour functions as the main thread weaving the stories together. Its variations create layers of meaning like superimposed coats of paint, creating patterns typical of Byatt's writing process: "These fundamental markings, analogies, recurrent spots of colour, were mnemonics in the texture of my text [The Virgin in the Garden], like patterns in embroideries or knitting, holding together the very personal and the largely cultural, the factual and the mythic" (Byatt 1998, 64). 
2 Thus, for Byatt, colours are first and foremost eloquent. She uses a wide array of grammar, semantic and poetic devices to depict colours. Little Black Book of Stories provides the reader with a most extensive spectrum of such devices. Byatt handles colours both directly-using adjectives-and indirectly-using idiomatic expressions and compounds. She enriches them semantically and grammatically with descriptions of her own so that they take on a particular poetic significance which varies with each tale's specific content. In place of the usual symbology to which she occasionally and knowingly refers, Byatt creates her own hermeneutics with colours. Their function, however, is to convey the silence of representation through sublimity. Laurence Petit's argument that Byatt's short story "The Chinese Lobster" works "as a symbolic and cathartic crossing of abjection and death before an epiphanic re-awakening of life" (Petit 118) can also apply to the collection Little Black Book of Stories. More specifically, Little Black Book of Stories works to transform the abject body into sublime art. Indeed the blackest aspects of the mortal body are painted colourfully so that the reader hesitates between disgust and admiration, a mixed feeling akin to that of the sublime. Our contention is that colours are used as a paste in stories which work on the limit (limes) of the unspeakable horror within and stand on the threshold (limen) between brilliance and terror. Through a detailed analysis of the tales, this article aims at providing an insight into the specificity of Byatt's writing in relation to colour and art.

\section{Domestic Turmoil}

The title of the collection invites the reader to pay special attention to all mentions of black be they direct references to the colour itself or oblique hints in idiomatic expressions or compound words. Thus it is highly significant that the opening story "The Thing in the Forest" and the closing story "The Pink Ribbon" are set partly during the war's blackout. The trauma of the blitz frames the entire collection and Byatt plays with words here, as the two stories focus on the workings of memory with characters blacking out on the traumatic event.

"The Thing in the Forest" tells of World War 2's children evacuees in the form of a fairy tale with Penny and Primrose symbolically facing the horrors of the war when meeting with a giant worm in the forest, the text "blending elements of realism and fantasy, [in an] attempt to reimagine the horror and chaos of the war by giving it a mythical form" (Alfer and Edwards de Campos 116). Although they have difficulties remembering the actual war-"They found it hard, after the war, to remember [...] The claspers of memory could not grip the drowned and the burned." (17-18)-they do remember the Thing "clearly and daily" (34). What has been obliterated is their childhood. Thus, when they go back, as adults, to the place where they were evacuated, "there was no mention of the evacuees whose presence appeared to have been too brief to have left any trace" (20), "there was all that history, but no sign that they, the children, that was, had ever been there" (23). Similarly, the child Alys, who used to follow them around, and never came back from the forest, has been eclipsed: "Nobody ever asked where she was, or looked for her" (25). The eclipse is further reinforced as the original children story narrated in the first pages does not mention the disappearance of Alys. Penny and Primrose's adult lives read as a compensation for the childhood lost in the woods: "Penny became a child psychologist working with the abused, the displaced, the 
disturbed" (18-19) and Primrose, who tells stories to children in shopping malls, is possibly the narrative voice at the beginning of the text.

"The Pink Ribbon" tells of the struggles of a husband with his wife suffering from Alzheimer's, a permanent case of blackout. Her name, Madeleine, cruelly echoes with a reference to Proust. The husband calls her mad Mado (228) and compares her to a "zombie" (208) and, in her confused state, she conjures up addled memories from the days of the blackout, and peoples the house with walking dead. Ironically enough, she has finally completed the injunction she gave him during the war to "forget it all" (210) and the memories come back all muddled: "She had forgotten it all, and it all flew about in threads and fragments" (210). This, in turn, plunges the husband into his own memories of the war, especially the fine line between life and death. He remembers people he thought dead suddenly "turn[ing] up on the doorstep" (225) or homeless people sleeping on the street "dreading to stir them, in case they were dead" (225). He compares dealing with his wife's condition to his "duty" as a "soldier" (225) during the war. His wife ultimately comes back from the world of the living dead in the form of a folk figure: a Fetch, an embodiment of Mado's lost mind. The Fetch goes by the name of suicide figure Dido and has come to beg the husband to kill Mado.

Thus the national domestic upset of the war's blackout is complemented by the torment of traumatic memories and their inscriptions on the body. The collection explores the internal workings and disturbances of the mortal body as a decaying body, a sick body, a wounded body or a body left without a mind. A great variety of colours are used to depict the horror of the body.

7 The giant worm in "The Thing in the Forest" is "the colour of flayed flesh [...] every colour, from the green of mould to the red-brown of raw liver, to the dirty white of dry rot" (14); "it was made of rank meat [...] but it also trailed prostheses of man-made material" (15). The alliterative sounds "flayed flesh", "red raw" and "dirty dry" complement the detailed descriptions of the colours themselves. The mould and the rot depict the worm as an unknown decaying body while the flayed flesh and the raw liver suggest an écorché (see Byatt's use of the art history term in "Body Art", 89). The allusion to the prostheses puts one in mind of the body parts lost in the war and of the war wounded, making the worm an embodiment of the blackout as a sudden overwhelming darkness: a decaying body politic, an écorché body of troops. It also refers to the "amputated families" (18) like Primrose's and Penny's who both lost their father during the war. Colours are the means used to describe the horror of the thing which, as adults, Penny and Primrose come to think of as "a real thing in a real place" (17) that the exceptional situation of the war has unveiled.

In "The Pink Ribbon", the husband uses colour to take revenge on his wife's condition. He decorates her hair with a pink ribbon while she always hated pink as it was a "babyish" (219) colour. ${ }^{2}$ Because she has lapsed into second childhood, he treats her as he would a little girl. Thus he buys for her the green teletubbie Dipsy and thinks: "It's a slightly bilious green and the name's appropriate" (205). The toy's name and colour express how his wife's condition makes him sick. He stabs it with hairpins in its belly as he would a voodoo doll, a black magic practice matching the zombie reference. The Fetch reproaches him with his choice of colours and brings to his wife the red teletubbie Po because red is her favourite colour. But in Po, the husband only sees his wife's mindless body and her second childhood: “'Po is even nastier,' he said defensively. 'Potties it means. Pot-bellies."' (219). Thus colours, at least for the 
husband, condense the horror of his wife's situation so that the pink ribbon is an ironical play on the contrast between the conventionally childish, girly colour and the terrible childishness of his wife, her impotence.

"Raw Material" is the story of a creative writing teacher and one of his pupils, Cicely Fox, an old lady whose pieces of writing for the class are embedded in the text. The two pieces are dedicated to the homely domestic toils of black-leading - How We Used to Black-Lead Stoves-and boiling the whites-Wash Day. The two opposite colours are enhanced, one grammatically with the use of a compound, the other stylistically with the use of a metonymy. It mirrors Byatt's fascination with the names of colours as standing on the limit of the unspeakable:

I think the names of colors are at the edge between where language fails and where it's at its most powerful. One of the things I noticed when I was working a lot on van Gogh in Still Life was how he doesn't decline his color adjectives. It is as though all the colors remained things. So if you're talking about quelque chose blanche he just leaves it as blanc. Apparently you're allowed to do this because it isn't quite clear whether they are nouns or adjectives. That in itself is very beautiful. (Byatt 2011)

The unspeakable once again concerns the body as the domestic tasks described in the pieces are a way to evoke the body's workings as well as the sick and poisoned body. Cicely thus equates the stove with the body ("our own internal combustion of matter" 170) when she remembers how they used to be "fed on charcoal for stomach upsets" (170). The soiled sheets in Wash Day recall "bodily fluids [...] we didn't like to think of" (186) as results of such combustion. At the same time as she draws a parallel between stove and body, Cicely also recalls the toxicity of domestic fuels and industrial fumes. They used to black-lead stoves, she says, in order to prevent soot from infiltrating their hair and skin: "particles may settle on one's own hair and scalp, a soot-plug for every pore in the skin of the hands" (171). She evokes the toxicity of black-lead and whitelead as well as of the dentist's quicksilver and also remembers the poisonous sulphur "a vile, yellow, clogging deposit, which smeared windows and lips alike" (173).

11 The constant parallel drawn between the combustion of the minerals and that of the body in How We Used to Black-lead Stoves is echoed in the story "A Stone Woman". After the main character, Ines, has been operated on for a gangrenous gut, stones sprout on her body and she feels she is turning into a volcano, "[containing] a furnace" (134). The wound in her belly is "the colour-or a colour-of raw flesh, like an open whip-wound or knife-slash" (118) that "had pushed out ruddy veins into the tired white flesh" (119) and "was many reds, from ochre to scarlet, from garnet to cinnabar" (119). As in "The Thing in the Forest", bodily elements are used to describe colours, more particularly a comparison with wounds in the body inflicted with whip or knife. The ghastly description contrasts with the precision of her words to describe the reds with terms used by painters. It anticipates the development of the story which will gradually discard the petrifying process as a metaphor for death and make Ines appear as a "walking metamorphosis" (149), the embodiment of an artistic process.

\section{Body Art}

12 The various descriptions quoted beforehand are at once terrifying or disgusting in their evocation and beautiful in their precision. As Jack Smollett, the writer teaching creative writing in "Raw Material", remarks: Cicely's pieces "work on more than one level at once" (179). The same applies for Byatt who superimposes meanings as she 
would coats of paint and uses colours that are not "easy on the eye" (57) and whose meaning is never stable but varies depending on the light she chooses to cast on them.

This is echoed in Cicely's writing and its many allusions to layers, "compacted layers" (169), "careful layers" (172), "the sheen [...] built up layer by infinitesimal layer" (172). This is akin to the writing process Byatt developed in The Quartet which she called "laminations": "Verbal lamination is a metonymic restructuring of experience in which contiguity and displacement replace similarity and substitution. Metonymy allows colors to play against each other as in the virtual space of painting. The focus is visual: there is no substitution of a metaphoric or symbolic signified for color itself" (Stewart 500). The colours used by Byatt are not metaphoric. Instead, she accrues meaning through comparison and metonymy so that colours become polysemic in their evocations. Cicely's pieces are emblematic of Byatt's laminations: black-leading evokes, in turn, the domestic process of cleaning the stove, bodily combustion, consumption and advertising with the furnace's trademark, a phoenix, which, by hinting at rebirth, is also evocative of Cicely's artistic process of reawakening past memories. Through the poetic creation of her own colour semantics, Byatt manages indeed to blend "the very personal and the largely cultural, the factual and the mythic". The same patterning process applies to Wash Day. Cicely recalls using popular Reckitt's Blue to whiten the sheets and describes the optical process by which blueing serves to enhance the whites' white: "It was an inversion, a draining. For when you held up the sheets, and took them from the blue water to drain them, you could see the blue run away and the white whiter, blue-white, a different white from cream, or ivory, or scorched-yellow white, a white under blue dripping liquid that had been changed, but not dyed" (185). The insistence on colour through the variety of the grammar usage and even metamorphoses such as the metonymic "whites" or the gerund "blueing", the compounds and the comparative, transforms the domestic task into an artistic experiment so that Reckitt's Blue comes to sound like an artistic process recalling Klein's Blue. Similarly to make the whites whiter, which sounds like advertising, comes to take a highly significant meaning in the general arrangement of the tales because, as Cicely writes, "words are needed for extremes of blackness and brightness" (168). Thus "using color words substantively as well as adjectivally, juxtaposing them in series, and drawing a lexicon from the paint-box are among Byatt's means of achieving sensory density" (Stewart 495).

"A Stone Woman" takes the process even further by presenting the reader with lists of strange words. Strange because they are scientific words defying the reader's comprehension and even his/her ability to pronounce them. In that particular case, colours bridge the gap between signifier and signified that the text slashes open, they are the only familiar elements the reader can hold on to. To quote but a few examples in a text rife with such lists: "she surprised a bubble of rosy barite crystals, breaking through a vein of fluorspar, and opening into the form of blue john" (122), "The two she loved most were labradorite and fantomqvartz. Labradorite is dark blue, soft black, full of gleaming lights, peacock and gold and silver, like the aurora borealis embedded in hardness" (137). The inclusion of such lists serves to mimic the character's puzzlement at her own transformation, all the more so as she is a lexicographer. It also conveys the actual transformation of Ines into an inhuman troll woman, unable to decipher words; in other words, the transformation of a woman who is old from a human perspective into a geologically young and lively mythical creature. Finally, it 
corresponds to her metamorphosis into a work of art in the hands of an Icelandic sculptor who works on the sedimented layers of her new body to reveal its colours, "to bring out the lights and the angles" (137). Byatt's fascination for taxonomy is not new. Her work regularly displays such lists. In Possession, it is the starting point of Roland's writing career: he writes lists of words (431) that will later arrange themselves into poems (475). The stone woman is an embodiment of the same process: her body sprouts a lexicographic feat of stony words that turn her into a walking poem, "a walking metamorphosis" (149). In an essay on Still Life, Byatt explains how the naming process and the classifying process serve to problematize "the relation of words to things, inventive, imprecise, denotative, practical, imagined" (Byatt 1993, 13). The fantastic thing that the stone woman's body has become defeats language. Words become grotesques (in the original art sense of the word) similar to the stone woman herself. The stone woman also defeats metaphor as instead of turning to stone with petrification standing for death, she turns into metonymic stones. In this short story, Byatt's writing imitates that of the painter and of the sculptor to upset the reader's expectations born of a long-standing tradition of mythical metaphors (Pygmalion and the like) and remedy the inescapable mortal fate of the body: the menopausal woman who expects dryness turns into a gushing volcano, human old age transforms into geological youth, the ordinary woman becomes a mythical creature, the human character is metamorphosed into a walking work of art. Colours are a way to approach the thing that is the body. If, at first, Ines thinks of her transformation as "the blemish" (119), which, etymologically, means to lose colour, from the French "blêmir", she gradually comes to see the beauty of it and the analogies she draws turn from disgust to wonder: "One day, one of the blue veins on her inner thighs erupted into a line of rubious spinels, and she thought of jewels before she thought of pustules" (120). Byatt works with colours and the contiguities they create in the tales to transform "Raw Material" into "Body Art", to use two of the stories' titles.

Quite tellingly, in "The Thing in the Forest", the place where the children have been temporarily evacuated is both "a hospital for the long-term disabled, and a secret store of artworks" (7). Byatt's work in the tales is about transforming body parts or the body's deficiencies into artwork. This is what happens in "Body Art" narrating the affair of an obstetrician with a woman artist. The hospital where he works houses a collection of medical relics like "ivory and ebony syringes" (72), "lead and silver artificial nipples" (73), prostheses and "small ivory women" with "removable [...] naveland-stomach" (74) which the woman artist he hires to classify them steals to make an Arcimboldo-like black écorché sculpture of Kali which questions birth, abortion and motherhood with references to the Virgin Mary. The story draws a parallel between the medical, artistic and religious treatments of the body, the surgeon being both an art collector and a lapsed Catholic. The text evokes Christ's birth as the woman artist decorates the Gynae Ward for Christmas-" putting the really colourful bits at the miserable end" (65) where the mothers of stillborn or sick babies are kept-and the obstetrician delivers the Christmas baby who is black twins-yet another use of the black colour. It also refers to resurrection and the reverence for body parts that are relics, which brings to mind transubstantiation. This transformation of Christ's body or the saints' bodies echoes the artistic metamorphoses in the tales: a transfiguration takes place in which colours play a major role. 


\section{Sublimity} define the sublime which Edmund Burke described as a delightful shudder mixed with terror and Kant as a simultaneity of the feelings of pleasure and displeasure created by the greatness that is the Thing which exceeds representation, more particularly for Kant, nature. This is precisely what "The Thing in the Forest" describes. The grown-up Primrose is the narrator of the story which, as a professional storyteller, she tells to children "offering them just a frisson of fear and terror that made them wriggle with pleasure" (19). The description she gives of the wood, both real and imagined, echoes the mixed feelings of pleasure and displeasure from which terror arises according to Kant and Burke: "The wood [...] had always been simultaneously a source of attraction and a source of discomfort, shading into terror" (27). The extremes of brightness and darkness are to be found in the wood where "the gold and the shadows were intertwined" (27). And it is because "Primrose knew that glamour and the thing they had seen came from the same place, that brilliance and the ashen stink had the same source" (32) that she can weave them into a tale. Byatt already drew that conclusion in a previous short story "Dragon's Breath", to be found in the collection The Djinn in the Nightingale's Eye, which anticipates "The Thing in the Forest" as it similarly describes the path of destruction of giant worms as an allegory for the pandemonium of war-the story itself was commissioned at the time of the siege of Sarajevo. Once the worms have gone away, the villagers start telling stories about them: "And these tales, made from those people's wonder at their own survival, became in time [...] riddling hints of the true relations between peace and beauty and terror" (Byatt 1995, 92). To turn those feelings into tales or artistic productions allows sublimation, that is, the possibility to represent the failure of representation.

The body in Byatt's work opens up a representational gap which she endeavours to bridge through sensory patterning inspired by painting. In the contemporary era, the body has become the thing which exceeds representation, combining the sublime with the abject as Catherine Bernard points out: "[the contemporary writers'] is a dark and more often than not abject form of sublime, 'written on the body,' a body made [...] too organic to be fully integrated. [...] The body disintegrates language, dismembers or dislocates it" (Bernard 177). The stone woman's body adorned with words like grotesque sculptures is evidence of it. The dizzying array of analogical patterns woven into Byatt's writing, especially with colours, corresponds to a postmodern form of the sublime which Catherine Bernard associates with a dissemination of meaning through "the uncontrollable proliferation of analogy [which] cancels both the use and the exchange value of the sign left to a gratuitousness" (Bernard 172). Indeed, it is almost impossible to account for all the connections established in the tales through the semantic and grammatical metamorphoses of colours. Such impossibility arises from the terror of bodily experiences. Thus, referring to the scene of Stephanie's labour in Still Life, Mariadele Boccardi notes: "Byatt faces the representational problem of providing verbal expression to her characters' experience and resorts to a strategy comparable to her description of Marcus's synaesthetic episodes, namely, analogy. Because the subject is bodily sensation, it is conveyed by words-adjectives especiallyreferring to other insights gained with the senses" (Boccardi 57). Byatt's writing is driven by the need to provide the most precise descriptions using a plethora of 
adjectives $^{3}$ to achieve accuracy in order to actualize the thing itself, a form of ideality: "I wanted my thoughts, my descriptions, to move between simply naming, like Proust's clear and usual images, and the kind of mental icons which are Mallarmé's languageflowers or the Sunflowers-'l'idée même et suave, l'absente de tous bouquets"' (Byatt 1993, 12). Byatt is fascinated by the "thingness" (Byatt 1993, 9) that painting represents and endeavours, through the use of colour words, colour analogies, colour metonymies to render the terror of the body, its eclipse from language, its transformation into art.

The fragile mortal body is thus both terrifying and brilliant in the tales and colours are the means to convey this ambiguity. They work both ways. Thus the furnace both comes to represent the life of the body ("the hidden red and gold roar [...] safely inside" 175) and evoke its death as Cicely closes her piece referring to cremation ("Nowadays, of course, we all go into the oven" 175), which is echoed in the death of Primrose's father in 'The Thing in the Forest', a fireman killed during a bombing who "vanished in an oven of red-yellow roaring" (39). Black-leading testifies to both the lifelong effort to make the home comfortable ("we put so much human blood and muscle into embellishing our houses with careful layers of mineral deposits", 172) and the turning to ashes which the soot-covered bodies anticipate. The reference to the "cinders that fell from the mouths of bad children in fairy-tales" (170) also echoes "The Thing in the Forest". White-lead both embellishes and poisons: "the white-lead with which the Renaissance ladies painted their skins and poisoned their blood. 'Let her paint never an inch thick, to this favour shall she come"' (174). Byatt twists Hamlet's famous reflection on mortality inspired by the contemplation of Yorick's skull (Shakespeare, V, 1, l. 189-190, 1156) by adding "never" as if to forewarn the ladies not to poison themselves and thus empties the quote of its irony on vanity. Instead, Byatt looks benevolently on lifelong efforts to accommodate mortality as they are a driving force for writing. Thus Jack Smollett, the creative writing teacher, is inspired by the multi-layered tales of Cicely, they make him want to write, whereas when he discovers her dead body at the end of the story with its "layers and layers of old scars" (195) testifying to some kind of torture, he develops a writer's block.

Something is needed to get past the horror and write again, colours are a means to do it. In "The Thing in the Forest", Penny goes back to the forest and never returns while Primrose, the narrator, transforms her experience into a colourful tale she tells children. Appalled at his wife's regression, the husband in "The Pink Ribbon" imagines telling a friend this "tale of strangeness" because "it had an aesthetic horror to it that was pleasing" (207). The text then turns fantastic to accommodate the terrible demand for euthanasia, the Fetch in her sexy red dress asking the husband to terminate the life of the "miserable hulk decorated with a pink ribbon" (235) as he had no problem killing "all those young Germans in the war" (235). Colours bridge the gap between brilliance and terror as they form elaborate patterns of varying meanings. Byatt herself explains she thinks of her books in patterns of colours. This one was her black book and its sublime quality of standing on the limit, the threshold between brilliance and terror is coherent with the ancient distinction described by Michel Pastoureau between two blacks, a beautiful brilliant one and a disquieting matt one, niger and ater in Latin (Pastoureau 96): "There were so many different blacks [...] Coal has its own brightness, a gloss, a sheen. [...] Coal is glossy. Coke is matt [...], the dust on coal glitters like glass dust, the dust on coke absorbs light, is soft, is inert" (169). Byatt again remarked on those two qualities of the black later when admiring the work of ceramist Edmund de Waal: "A glossy black pot makes a light in darkness-a matt black pot absorbs light 
from the shiny pot and from the lead around it, becoming a kind of memory of a pot" (Byatt 2014). In Little Black Book of Stories, she has worked with colours to convey the light in darkness, the imprint of memory and the failure of representation. Byatt appropriates both the opacity and the aura of the sublime's black magic.

\section{BIBLIOGRAPHY}

Alfer, Alexa and Edwards de Campos, Amy J. A.S. Byatt. Critical Storytelling. Manchester and New York: Manchester UP, 2010.

Bernard, Catherine. “A Certain Hermeneutic Slant: Sublime Allegories in Contemporary English Fiction”. Contemporary Literature 38.1 (Spring 1997): 164-184.

Boccardi, Mariadele. A.S. Byatt. Basingstoke and New York: Palgrave Macmillan, 2013.

Burke, Edmund. A Philosophical Enquiry into the Origin of Our Ideas on the Sublime and the Beautiful (1757). Adam Phillips (ed.). Oxford: OUP, 1990.

Burns, Carole. "Off the Page: A.S. Byatt". The Washington Post, 22 April 2004. http:// www.washingtonpost.com/wp-dyn/articles/A17290-2004Apr16.html [21/05/14].

Byatt, A.S. "Porcelain ghosts: the secrets of Edmund de Waal's studio". The Guardian, 2 May 2014. http://www.theguardian.com/artanddesign/2014/may/02/edmund-de-waal-potter-ceramicsessays-as-byatt [21/05/14].

Byatt, A.S. “The Art of Fiction n'168”. Interview by Philip Hensher. The Paris Review 159 (Fall 2011).

Byatt, A.S. « Rose par A.S. Byatt: le spectre du rose ». Le Monde des livres, 22 juillet 2010. http://www.lemonde.fr/livres/article/2010/07/22/rose-par-a-s-byatt-le-spectre-durose_1390851_3260.html [21/05/14].

Byatt, A.S. Little Black Book of Stories (2003). London: Vintage, 2004.

Byatt, A.S. "Memory and the Making of Fiction". Patricia Fara and Karalyn Patterson (eds). Memory. Cambridge: CUP, 1998, 47-73.

Byatt, A.S. The Djinn in the Nightingale's Eye: Five Fairy Stories (1994). London: Vintage, 1995.

Byatt, A.S. "Still Life/Nature morte". Passions of the Mind (1991). New York: Vintage International, 1993, 3-13.

Byatt, A.S. Possession: A Romance (1990). London: Vintage, 1991.

Kant, Immanuel. The Critique of Judgement (1790). Trans. James Creed Meredith. Oxford: Clarendon, 1952.

Pastoureau, Michel et Dominique Simonnet. Le Petit Livre des couleurs (2005). Paris : Seuil, « Points Histoire ", 2007.

Petit, Laurence. "Textual and Pictorial Distorsions: Sublimity and Abjection in A.S. Byatt's 'The Chinese Lobster". Études britanniques contemporaines 31 (2006): 117-126. 
Shakespeare, William. Hamlet. Stanley Wells and Gary Taylor (eds). The Complete Oxford

Shakespeare, vol. III, Tragedies. London: BCA, 1121-1163.

Stewart, Jack. "Ekphrasis and Lamination in Byatt's Babel Tower". Style 43.4 (Winter 2009):

494-516.

\section{NOTES}

1. "Still Life started out very dark purple, and then I felt there ought to be yellow, it was the complementary color to the purple, and because I felt there ought to be yellow, I thought of Van Gogh's chair, and in fact van Gogh became an important symbolic figure in that book. He got in because of the color yellow" (Burns).

2. On the many aspects of the pink colour, see A.S. Byatt, « Rose par A.S. Byatt: le spectre du rose ». Le Monde des livres, 22 juillet 2010.

3. "What interested me was the abused and despised adjective, that delimiter of plain nouns which, if properly used, makes every description more and more particular and precise." (Byatt 1993, 11)

\section{ABSTRACTS}

Colours in Byatt's collection of short stories are either organic or related to the body, which is consistent with the stories as tales of domestic horror depicting the decaying body, the tortured body, the écorché body or the body left without a mind. Byatt is, in particular, a black magician evoking the horror within by making use of the domestic toil of black-leading or the domestic upset of the war's blackout to build a sophisticated metaphor of the work of art as metamorphosis. Working like a painter incrementing layers upon layers of meaning like so many touches of colour or coats of material, Byatt's use of colour is a subtle means to work on the limit (limes) of the unspeakable and stand on the threshold (limen) between brilliance and terror so that she may transform Raw Material into Body Art as two aptly named stories suggest. Working with colours, she paints the body sublime.

L'usage de la couleur dans le recueil d'A.S. Byatt se concentre sur les façons de dépeindre le corps, les nouvelles mettent en scène une forme d'horreur domestique explorant les facettes du corps mortel : corps écorché, corps malade, corps torturé, corps sans âme. Byatt use de la magie du noir pour évoquer l'horreur : bouleversement domestique provoqué par la deuxième guerre mondiale lors du black-out de Londres, labeur domestique quotidien de frotter les fourneaux à la mine de plomb (en anglais black-leading). Byatt use de magie noire pour construire une métaphore de l'œuvre d'art comme métamorphose. Travaillant à la manière du peintre, Byatt superpose les couches de sens et utilise la couleur pour explorer les limites (limes) du dicible et les zones liminales (limen) entre éclat et terreur afin de transformer Le matériau brut en Art corporel, pour reprendre les titres de deux nouvelles. La couleur aide Byatt à peindre un corps sublime. 
INDEX

Mots-clés: noir, black-out, corps, sublime

Keywords: black, blackout, body, sublime

oeuvrecitee Little Black Book of Stories

\section{AUTHORS}

\section{ÉMILIE WALEZAK}

Émilie Walezak est Maître de conférences à l'Université Lumière-Lyon 2 dans le laboratoire LCE. Elle a publié plusieurs articles sur l'œuvre d'A.S. Byatt, Jeanette Winterson, Rose Tremain et a codirigé l'ouvrage A Myriad of Literary Impressions : L'intertextualité dans le roman contemporain de langue anglaise paru en 2010 aux Presses Universitaires de Perpignan. 